\title{
MARTTA HEIKKILÄ
}

\section{MONIN VEDOIN:}

\section{NANCY PIIRTÄMISEN MERKITYKSESTÄ}

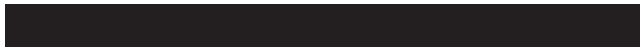

Jean-Luc Nancyn filosofiassa piirtäminen on kuvataiteen alku. Ensi sijassa piirtäminen merkitsee Nancylle vielä muotoutumatonta, tyhjästä syntyvää muotoa: se merkitsee asioiden ainutkertaista alkua ja avautumista vailla annettua mallia. Samalla piirtäminen tarkoittaa taitoa tuottaa kuvia. Piirrokset tuovat Nancyn mukaan esiin yhtäältä piirtämisen eleen ja sen vaatiman energian ja voiman, toisaalta piirroksen muodon sulkeutumattomuuden ja täydentymättömyyden. Merkityksellistä ei siten ole niinkään piirroskuvien kyky esittää tai jäljentää todellisuutta tavanomaisessa representaation mielessä. (Nancy 2009, 9-13.)

Piirrokset osoittavat, että jokaisen viivan vetäminen on jonkin asian avautumista päättymättömän alkamisen merkityksessä. Piirustus on ikuisessa syntymisen tilassa, eikä sen todellisuus ole täydellistä. Sitä vastoin piirros näyttää koko todellisuudessa vallitsevan keskeneräisyyden ja sen, miten oleminen on jatkuvaa aloittamista alusta (vrt. mt., 16). Nancyn ajatuksessa piirtämisestä kyseenalaistuu taidetta perinteisesti luonnehtiva muodon ja aineen erotus: entä jos muotoa ei koskaan olekaan sellaisenaan, jo olemassa maailmassa, vaan muodot piirtyvät esiin jokaisessa viivassa ja antavat itse itselleen hahmon? Kuten Nancy huomauttaa, juuri piirrokset edustavat hänelle muodon elementtiä, jopa paremmin kuin mikään muu. Tarkastelen artikkelissani piirtämisen ontologista merkitystä Nancyn filosofiassa.
Laajemmin piirtämisen analyysi tuntuu Nancylle kertovan tavasta, jolla asiat syntyvät. Tarkastellessaan piirtämistä hän lähtee liikkeelle alun perin platonilaisesta totuuden ajatuksesta, ideasta eli vain järjen avulla käsitettävistä malleista. Sanaa "idea" hän käyttääkin paikoitellen "muodon" synonyymina - tätä Nancy perustelee siten, että myös Platonin "idea", eidos, viittasi"näkyvään muotoon" (mt., 14; vrt. Platon, Valtio 508c-509a). Platonin ideaopista Nancyn ajattelu kuitenkin poikkeaa: piirroksissa Nancya ei kiinnosta niiden tapa esittää todenmukaisesti abstrakteja tai konkreettisia kohteitaan. Hän tunnistaa piirroksissa jännitteen valmista, annettua muotoa koskevan ajatuksen ja sen piirroksessa ilmenevän vääjäämättömän epätäydellisyyden välillä. Muodot eivät ole Nancylle yliaistisia ja universaaleja, vaan jokainen piirros ilmentää omaa muotoaan: muoto merkitsee asioiden yksittäisen, ainutkertaisen mielen avautumista, joka ei ole muuttumaton vaan päinvastoin aina vasta liikkeessä kohti itseään. Piirros myös sisältää sattumanvaraisia elementtejä, sillä piirtäjän työn ytimessä, eleessä, on myös jotakin hallitsematonta, johon intentiot eivät yllä (Nancy 2010, 97).

Nancyn laajassa tuotannossa kuvataide on merkittävä teema. Kuvat alkoivat kiinnostaa Nancya filosofisesti viimeistään 1980-luvulla, ja sittemmin taiteesta on tullut yksi hänen koko ajattelunsa tärkeistä aiheista. Nancy on kirjoittanut useita tutkielmia maalauksista, 
mutta myös kuvan (image) käsite yleisemminkin ja 2000-luvulla erityisesti piirtäminen ovat hänen aiheitaan (esim. Nancy 2003, 2007, 2009). Jo vuonna 1994 Nancy julkaisi teoksensa Les Muses, jossa hän muotoili tiiviisti käsityksensä taiteen ontologiasta esseessä "Pourquoi y a-t-il plusieurs arts, et non pas un seul?" - "Miksi taiteenlajeja on useita, eikä vain yhtä ainoaa?"(Nancy 1994,11-70). Tämä teksti tuo esiin Nancyn taidekäsityksen ehkä kaikkein syvimmän ja perimmäisimmän aiheen, moninaisuuden. Taiteellisten esitysten loputon määrä, teosten sisäinen moninaisuus ja samalla lukemattomat tavat ottaa taidetta vastaan ovat myös hänen piirtämisen ajattelunsa ytimessä.

Nancyn ontologia, olemisen ajattelu, perustuu käsitykseen siitä, että oleminen on perimmältään praktista, todellista ja käytännöllistä: oleminen on maailmassa olevien asioiden ainutkertaista, yksittäistä olemassaoloa. Oleminen on aktiivinen teko ja toimintaa, joka syntyy ja tulee esiin asioiden välisissä suhteissa: siinä, miten asiat ilmenevät jonkinlaisina sen ansiosta, millaisen mielen tai tunnun (sens) ne kulloinkin saavat toisiinsa nähden. (Nancy 1998, 25-26.)

Toisin kuin perinteiset metafyysikot ovat esittäneet, Nancyn mukaan olevia on aina välttämättä useita. Ei ole olemassa vain yhtä, jakamatonta ja abstraktia olemisen kokonaisuutta, sillä tässä tapauksessa olevat eivät voisi olla todellisessa suhteessa toisiinsa eikä oleminen ilmenisi kulloinkin omien predikaattiensa mukaisesti eli tietynlaisena. Pelkästä singularisaatiosta eli tapahtumasta, jossa jokaisen olion yksilölliset ominaisuudet muodostuvat kullakin hetkellä, ei synny mitään, sillä asiat eivät luo itseään riippumatta muista olevista (Nancy 1992, 96). Sen sijaan olemista on tarkasteltava aina asioiden yksittäisestä olemassaolosta käsin - on vain "eksistoivien eksistoimista", ja eksistoivia asioita on lukemattomia (Nancy 1988a, 78, v. 1). Siksi voi olla olemassa vain singulaaristen asioiden olemista: on aina jokin tai joku, joka tulee esiin jonkinlaisena.
Oleminen on perustavassa mielessä monikollista (pluriel): oleminen toteutuu yhtä aikaa loputtoman monissa olevissa, aina jokaisessa kerrallaan ja partikulaarisesti. Olemista on etsittävä yksittäisistä olevista tai asioista käsin. (Nancy 1996a, 15-123.) Ei siis ole vain puhdasta, yleistä olemista, vaan oleminen on ajassa ja paikassa, asioissa, jotka ilmenevät meille aina omanlaisinaan. Nancylle oleminen tapabtuu siten, että se ottaa oman kulloisenkin paikkansa - näin oleminen merkitsee kunkin asian ainutkertaista olemassaoloa. Maailmassa on olemista vain yksitellen.

\section{TAITEEN MONEUS}

Sama periaate ilmenee myös taiteessa, sillä taiteenkin olemassaolo perustuu moneuteen. Nancyn väitteen mukaan "taide" ei milloinkaan ole yksi, ja siksi onkin tavallaan paradoksaalista, että hän lakkaamatta puhuu "taiteesta" yksikkömuodossa. Taiteen käsitettä ei nimittäin ole koskaan mahdollista määritellä, sillä ei voida nimetä yhtäkään ilmiötä, joka sellaisenaan vastaisi sanaa "taide" (Nancy 1994, 11-12).

Ajatus taiteen perimmäisestä moninaisuudesta vie varhaisromantiikan taidefilosofian jäljille. Romantikkojen, kuten Friedrich Schlegelin (1772-1829), mukaan esteettisen alue on autonominen eli filosofiaan ja moraaliin nähden itsenäinen (Schlegel 1971, 198, fragm. 252; ks. Saarinen 2011, 51-53). Samankaltainen autonomisuus on myös taiteen ja taidetta koskevien teorioiden lähtökohta: sen mukaisesti taiteella on käytössä vain sille ominaiset esityskeinot. Samalla jokaisen teoksen tai muun taiteen ilmentymän tehtävänä on ratkaista yhä uudelleen, mitä taide on ja millaisia ovat sen ilmaisumuodot. Siten taiteen ajatus on aina keskeneräinen ja täydentyy loputtomasti Schlegelin mukaan romanttinen kirjallisuus on aina "yhä syntymässä", ei koskaan valmis, vaan kehittyy alituiseen (Schlegel 1971, 175, fragm. 116; Saarinen 2011, 54). Jos sama asia halu- 
taan ilmaista kantilaisittain, taiteen todellisuus ylittää reflektion, toisin sanoen filosofian, lakkaamatta (Kant 1952, § 49). Taide kyseenalaistaa ja yllättää oman käsitteensä aina, kun uusi taideteos syntyy. Romantiikan taidefilosofiassa kukin teos ratkaisee yksitellen ja uudella tavalla, mitä taide on (Nancy 1994, erit. 21-24).

Sen lisäksi, että taiteen käsite ei sen muuttuvuuden ja jatkuvan muotoutumisen vuoksi ole määriteltävissä, Nancy on omaksunut varhaisromantiikan taidefilosofiasta toisenkin taiteen olemassaolon moninaisuutta koskevan ajatuksen. Tämä on käsitys taiteen perimmäisestä konkreettisuudesta. Taidetta voidaan etsiä vain sen todellisista ilmiöistä, joita romantikot - ja myös Nancy - kutsuvat fragmenteiksi (esim. Nancy 1993, 189-195). Taide ei avaa maailmaa asiana, jolla olisi jo jokin merkitys. Sen sijaan, että taide näyttäisi meille loppuun saatettuja, valmiiksi määritettyjä ajatuskokonaisuuksia, taide voi esittää vain muotoja ja hahmoja, jotka sinänsä ovat vailla merkitystä. Taide tuo maailman esiin pelkästään äärellisenä fragmenttina eli osana, ei kokonaisena maailmana. Taiteen esitykset näyttävät yhden mahdollisen näkymän tai maailman, mutta siten kuin taideteoksen maailma olisi itsestään irrallinen. Taide ei tuo esiin tunnettua maailmaa koskevia yhtenäisiä kuvia, vaan pikemminkin irrallisuuden figuureja: taiteellisia esityksiä, jotka oman erityislaatunsa vuoksi erottuvat muusta maailmasta ja pysäyttävät kokijan. (Nancy 2003, 29-30.) Tällaisia taideteoksen näyttämiä maailmoja on puolestaan lukemattomia, ja ne ilmenevät jokaisessa taideteoksessa.

Taide toisin sanoen esittää sen, että erilaisia maailmoja voidaan esittää monella tapaa (Nancy 1994, 61, 75). Vaikka Nancy puhuu "taiteen maailmoista", on huomattava, ettei hän tarkoita taideteoksen maailmaa samassa mielessä kuin Martin Heidegger esseessään Taideteoksen alkuperä (1935-36). Heideggerille teoksena oleminen tarkoittaa "maailman pystyttämistä" ja teoksesta paljastuva maailma omassa totuudessaan on historiallisen kansan asuinpaikka. (Heidegger 1995, 41, 44.) Heideggerin mukaan taideteokseen sisältyi siis mahdollisuus maailman pystyttämiseen historialliselle kansalle. Puhumalla "maailmoista" monikossa Nancy on halunnut järjestelmällisesti välttää Heideggerin käsityksen sisältämät poliittiset vaaratekijät. Tällöin taiteen esittämät maailmat viittaavat kuvien fragmentaarisuuteen ja epäjatkuvuuteen ja toisaalta myös lukemattomiin mahdollisuuksiin tuottaa ja tulkita taideteoksia.

Taide ei siis ole "yksi", ikuinen tai liikkumaton idea, eikä taideteos ole myöskään jakamaton kokonaisuus. Jokainen teos muodostuu loputtomista yksityiskohdista; taide on yksityiskohtien ja erojen tekniikkaa, joka tulee esiin kussakin teoksessa erikseen, aina eri lailla ja siksi paikallisesti (Nancy 1994, 41).

Taide on Nancyn mukaan olemassa aina monikossa eikä taidetta voi löytää käsitteestä vaan taiteen eri lajeista - siitä huolimatta, että niiden perinteiset rajat horjuvat, mikä on nykytaiteessa hyvin tuttu seikka - ja yksittäisistä teoksista. Samalla taiteen ilmiöt ovat äärellisiä, ainutlaatuisia tapahtumia. Taide on pääsyä"jäljittelemättömään” ja kääntymättömään, ilmaisuihin, joita - edelleen romantiikan ajattelun mukaan - ei voida tuottaa millään muulla tavoin. Jälleen seuraa paradoksi, sillä kun taide ilmaisee jotakin, se Nancyn mukaan ilmaisee ilmaisematonta: jokainen taideteos muodostaa absoluuttisen käännekohdan, jossa yksittäisen taideteoksen alku muuttuu koko taiteen alkuperäksi (Nancy 1996a, 33).

Nancyn käsitys taiteesta on nähdäkseni modernistinen ainakin siinä, että romanttisen perinnön mukaisesti taide merkitsee hänelle omalakista ilmaisun aluetta. Taiteessa eivät ole Nancyn mielestä tärkeitä niinkään kantilaisen estetiikan korostamat "kauneus", "ylevä", "tarkoituksenmukaisuus ilman tarkoitusta" tai "makuarvostelma". Taide ei myöskään ole Hegelin "yliaistisen Idean aistimellista esittämistä" eikä Heideggerin tapaan "totuuden asettumista teokseen tekeille", kuten Nancy huomauttaa (1996a, 33). Taiteen tarkoitus ei ole olla edes 
kuva taiteilijasta subjektina. Sen sijaan taide on asioiden näyttämistä, kuvia maailmasta, sen outoudesta ja maailman loputtomista tapahtumista (ks. Nancy 1994, 122).

Ennemminkin taide on pääsyä omaan pirstoutuneeseen alkuperäänsä, joka ilmenee taiteen lajien ja ilmaisumuotojen hajaannuksessa. Nancyn mukaan taide on "ainutkertaisen alkuperän moninkertaista koskettamista", jota juuri käsitys "luonnon jäljittelystä" on aina tarkoittanut (Nancy 1996a, 33). Näin sanoessaan Nancy ei kuitenkaan viittaa mimeettisyyteen tai representaation logiikkaan. Taide esittää kosmogonian, maailmankaikkeuden syntymisen, sellaisena kuin se on: välttämättä monikollisena, erilaistuneena, vähä vähältä, värin tai sävyn kosketuksena, nokkelana sanankäänteenä, materiaalin laskostumisena, säteilynä, tuoksuna, lauluna tai pysähtyneenä liikkeenä - juuri siksi, että taide synnyttää jonkin erikoislaatuisen maailman, yhden monien joukossa.

Teoksissa maailma syntyy konkreettisista hahmoista, väreistä, pisteistä. Seuraavassa tarkastelen piirroksia, jotka muodostuvat viivoista ja vedoista: piirtämisen osista.

\section{PAKENEVIEN VIIVOJEN LEIKKI}

Piirtäminen on Nancylle yksi kuvataiteen erityislaji, jonka ainesta on loputtomiin moninkertaistuva viivojen leikki. Nancy kirjoittaa piirtämisestä etenkin teoksissaan $\grave{A}$ plus d'un titre $^{1}$ ("Monin tavoin", 2007) ja Le Plaisir au dessin ("Piirtämisen ilo", 2009). Jälkimmäisessä hän puhuu piirtämisestä mutta myös sen rajatapauksista - jotkut Nancyn piirustusesimerkeistä ovat musteella maalattuja teoksia, ja joidenkin menetelmä lähenee grafiikkaa. ${ }^{2}$

Mikä sitten luonnehtii juuri piirtämistä, ja mikä erottaa sen kaikista muista kuvataiteen muodoista? Nancyn omat teosvalinnat osoittavat, että piirtämisen määrittely ei aina ole yksinkertaista. Tarkastelen seuraavassa kuitenkin piirtämistä sellaisena kuin se yleisimmin ymmärretään: kaksiulotteisena, viivan käyttöön perustuvana taiteen menetelmänä,jonka erottaa taidegrafiikasta ja muista kuvien monistamisen menetelmistä se, että piirtämisen alustana on suoraan paperin pinta tai muu taso. Ainakin osittain kysymys piirtämisen rajojen väljenemisestä viittaa nykytaiteilijoiden omaksumaan ajatukseen, ettei taiteenlajeja ole enää entiseen tapaan aina mahdollista erottaa esimerkiksi käytetyn välineen perusteella, vaan tekotapoja saatetaan yhdistellä hyvinkin vapaasti.

Piirtämisen aineksista tärkein on viiva. Se kuuluu kuvan muotoon vaikuttaviin osatekijöihin; muita ovat valööri eli värin tummuusaste sekä väri itse. Usein taiteilijat hahmottelevat myös maalauksensa piirtämällä sen kankaalle. Perinteisissä taiteen teorioissa 1500 -luvulta 1800 -luvulle asti eli aikana ennen abstraktia maalausta viivaa pidettiin maalaustaiteen perustana, sillä viivan katsottiin määrittelevän muotojen ja massojen sommittelun maalauksissa. ${ }^{3}$ Viivaa pidettiin ensi sijassa ääriviivana, ja sen käytöstä syntyi koko teoksen sommittelu. Viivan käytöstä paljolti syntyikin käsitys siitä, millaista klassisen maalaustaiteen ylipäätään tuli olla ja millaiseksi kuvan olemassaolo ymmärrettiin: viiva rajasi luonnossa näkemiämme elävien olentojen ruumiita, hahmoja ja esineitä. Siten viiva jäsensi koko kuvatilaa. 1900-luvun abstrakti taide kuitenkin muutti viivan merkityksen: hahmot ja muut kohteet puuttuvat, ja siten myös niiden ääriviivat. Tämä ei kuitenkaan vähentänyt viivan merkitystä. Vaikka konkreettisten hahmojen poistuttua taideteoksista myös niiden ääriviivat hävisivät, viivat säilyivät, sillä nyt niiden tehtävänä oli tuottaa näkyviksi taideteosten elementtejä eli myös abstrakteja, vain tekijän mielen sisäisiä kappaleita. (Barasch 1998, 341-343.)

Modernissa kuvataiteessa viiva ei yleensä enää merkitse kuvattujen kohteiden ominaisuutta eikä ylipäätään mitään maailmassa läsnä olevaa asiaa. Näkyviä viivoja ei edes ole luonnossa; vasta viivan käyttö taideteoksessa 
tekee olioita näkyviksi (vrt. Merleau-Ponty 2012, 461-463). Viivan merkitystä abstraktille taiteelle on tarkastellut esimerkiksi taidemaalari ja -teoreetikko Wassily Kandinsky 1910luvulla. Kandinskyn mukaan kapeassa mielessä viiva usein ymmärretään teoksen muotoja tuottavaksi tekijäksi, joka kuvassa rajaa pintoja toisistaan. Laajemmassa mielessä viivaan ja siitä syntyvään muotoon yhdistyy sisältö, ja näin muoto tarkoittaa rajauksen lisäksi "sisäisen sisällön" ilmausta. (Kandinsky 1981, 64.) Myös Paul Kleelle (1987, 23-29) viiva merkitsi yhtä taideteoksen toisiinsa saumattomasti liittyvistä muotoelementeistä. Valööreihin ja väreihin verrattuna viiva oli kuitenkin rajoitetumpi, koska puhtaalla viivalla on vain mitan ja mitattavuuden ulottuvuus - ääriviiva, ympärysmitta ja ala. "Viiva on pelkästään mitta", Klee totesi (mt., 27). Silti viivat eivät voineet tuottaa kuvaukseen näköisyyttä tai todenkaltaisuutta (mt., 58). Vaikuttaa siis siltä, että viiva on Kleelle ideaalinen ja järjellä käsitettävä yksikkö, mutta tästä huolimatta todellisuuden ja piirroksen suhde ei pelkisty suoraan vastaavuuteen. Tästä näkökulmasta Klee jakaa Nancyn käsityksen siitä, että viiva ei jäljittele maailmaa. Sen sijaan ajatus viivan lineaarisuudesta ja absoluuttisuudesta ei esiinny Nancyn piirtämisen filosofiassa.

Vaikka Nancyn näkemys viivan mimeettisyyden puuttumisesta vastaa Kandinskyn ja Kleen teorioita, hänen käsityksensä viivasta muistuttaa enemmän Maurice Merleau-Pontyn "Silmä ja henki" -esseessä (1960) esittämiä ajatuksia. Merleau-Pontyn mukaan viiva merkitsee taideteoksille rakentavaa voimaa. Viiva ei jäljittele olioita, eikä se itse ole olio. Sen sijaan viivan tehtävä on toinen: se tuo esiin asioiden synnyn. (Merleau-Ponty 2012, 462-464.) Ajatus piirrosviivasta olemisen syntymisen hetkenä sisältyy myös Roland Barthesin käsitykseen: viiva on työtä, energiaa ja näkyvää toimintaa," jonka tuloksesta näemme, mikä sen on pannut käyntiin ja [mikä sitä on] käyttänyt", kuten Barthes kirjoittaa analyysissaan yhdysvaltalaisen Cy Twomblyn teoksista
(Barthes 1989,161). Koska viiva on ruumiillisen työn tulos, se on samalla sekä jäljittelemätön että diskursseihin palautumaton.

Piirtämisen käsitettä luonnehtii Nancyn filosofiassa ensi sijassa kolme seikkaa: viiva (trait), muoto ja ero. Kenties enemmän kuin mikään kuvataiteen laji juuri piirustus merkitsee hänelle olemista muodon ja muotoutumisen rajalla. Piirustus on aina keskeneräinen: koska se muodostuu viivoista, jotka voivat periaatteessa monistua teoksissa rajattomasti, se ei milloinkaan ole vielä täysin valmis tai oma itsensä. Piirustus on aina vasta tulossa itsekseen. Siksi piirustus on ymmärrettävä aina joksikin toiseksi siihen nähden, mitä se on: piirros on eroa kaikesta mitä on, ja lisäksi se eroaa itsestään, siis omasta esityksestään. Eron ajatukseen puolestaan kytkeytyy kysymys piirtämisen muodosta: piirtäminen itse on muotoa. Se ei ole muuttumattoman, yliaistisen muodon jäljentämistä, kopioimista tai esittämistä toisessa hahmossa, vaan muodon tai idean syntymistä ja tulemista joksikin. Tästä syystä piirros itse on oma ideansa. Nancyn mukaan idea on piirroksessa hahmottuvan asian todellinen muoto. Piirroksessa muoto ja idea yhtyvät, sillä piirrettäessä muoto avautuu kulloistakin muotoutumistaan kohti, oli sen perustana sitten ajatus, tavoite tai päämäärä, jonka piirretty jälki voi muodolle antaa. (Nancy 2009, 19, 51.) Nancyn käsitystä vastaa myös se empiirisesti todettava seikka, että luonnossa ei ole ääriviivoja: ääriviivat ovat ihmisen keksimiä ja kuuluvat vain taiteen esityksiin.

Nancylle piirtämisellä on siten ontologista merkitystä. Piirtäminen osoittaa, miten syntyy käsite tai idea eli asioiden muoto (Nancy 2009, 43). Piirtäminen on kaiken alku, sillä se on taiteenlajeista muotoutuvin ja orastavin ja siten aina vasta alussa. Näin piirustus on myös ikuisessa syntymisen tilassa, koska sen todellisuus ei ole täydellistä. Kuten Nancy sanoo, piirretyt viivat on "aina löydettävä, avattava, jäljitettävä, pantava alulle, viillettävä auki” (mt., 16). Tämä tarkoittaa, että juuri piirustus syntyy ensimmäisenä tyh- 
jästä. Siksi piirustus voi olla synonyymi vielä viimeistelemättömille hahmotelmille, "luonnoksille" (esquisse) ja "harjoitelmille" (étude). Piirtäminen on jonkin alkamista toisessakin mielessä, sillä piirretty kuva on aina epätäydellinen: sen muoto on yhä avoin. Piirroksen muoto on vasta löytämäisillään itsensä, voi sanoa, että se etsii omaa jälkeään (se trace). Muotoa ei ole olemassa tätä ennen, sillä se ei sijaitse ideoiden maailmassa. Ennemminkin piirtäminen jatkuvasti yllättää piirtäjän, ja se on koko ajan liikkeessä. "Piirroksen tulevassa muodossa”, Nancy kirjoittaa,"sekoittuvat [piirtämisen] teko ja sen vaatima energia, eikä tämän teon tai tilan merkitystä [...] ole mahdollista täysin erottaa piirtämisen eleestä, liikkeestä ja sen muodostumisesta jonkinlaiseksi” (mt., 9).

Kirjoittaessaan piirtämisen teosta Nancy tulee - joskin negatiivisesti - määrittäneeksi piirtämisen ja ehkä kaiken taiteellisen työskentelyn perusteen, eleen tai teon (geste) (Nancy 2009, 48-55). Se ei ole yhtä kuin intentio tai taiteilijan mielessä oleva päämäärä hänen tehdessään teostaan. Ele ei ole myöskään liikettä eikä ääriviivojen antamista muodolle (Nancy 2010, 97). Ennemminkin ele on "aistimellista dynamiikkaa, joka edeltää tietoista merkitystä, on sen osa tai seuraa sitä". Vaikka itse eleellä ei olekaan merkitystä, tästä huolimatta ele on "aistimellista mieltä" (sens sensible). (Mt.) Nancy korostaa, että juuri ele havaitaan taideteoksessa. Siten ele on taiteen vähimmäisvaatimus. Samankaltaisen käsityksen eleestä on esittänyt Roland Barthes: Barthesille ele merkitsee varsinkin kirjoituksessa mutta myös muissa merkeissä ilmenevää teon tai toiminnan ylijäämää. Ele on jälki itse merkin tuottamisesta, ei kirjoituksen muoto eikä käyttötarkoitus, ei myöskään viesti tai merkki (Barthes 1989,152-153). Siten kirjoittamisen ele ei tuota välttämättä mitään muuta kuin tavan, jolla eleen olemus, näkyvä jälki, vaikuttaa kirjoituksen lukijaan tai taideteoksen havaitsijaan, joka kohtaa teoksen tekijän jälkeensä jättämän eleen - pelkistetyimmillään vain töherryksen tai tahran. Sen sijaan, että ele ilmaisisi valmiin merkityksen, sekä Nancyn että
Barthesin mukaan se näyttää tekijän toiminnan materiaalisen ylijäämän. Näin määriteltynä ele on verrattavissa myös Derridan "jäljen" käsitteeseen (vrt. Derrida 1967, 95).

Taiteilijan eleen erottaa kaikesta muusta toiminnasta se, että juuri eleen näkyväksi tekemä asia synnyttää kokijassa iloa, eikä esimerkiksi esitetyn asian tuottama hyöty. Eleen merkitys taideteokselle on Nancyn mukaan mahdollista rinnastaa samankaltaiseen pyyteettömyyteen, joka Kantin mukaan on ominaista esteettiselle arvostelmalle: arvostelman kohde on arvokas oman itsensä ja esteettisen tarkastelun vuoksi, ei siksi, että se täyttäisi jonkin ulkoisen tarkoituksen. (Nancy 2010, 97; Kant 1952, § 6.)

Piirtämiselle on ominaista, ettei mikään aikaisempi muoto tai merkitys määritä sitä, miten piirroksen viiva vedetään, eikä sen hahmoa ole olemassa ennalta (Nancy 2009, 12). Nancyn mukaan jopa maalaus on luonteeltaan piirustusta paljon tarkemmin pobjustettua (fondée) ja perustuu sitä kiinteämpiin elementteihin, eikä ole siis yhtä vapaata kuin piirtäminen. Maalauksissa asioiden läsnä oleminen ei kuitenkaan ole luonteeltaan staattista, vaan pohjan ja hahmojen suhde määrittyy koko ajan uudelleen ja ne voivat olla olemassa vain toistensa ansiosta (Nancy 2003, 30-33). Piirustuksen tapaan myös maalaus on Nancylle "näyttämö" ja "pinta", jolla on kuitenkin plastisuutta eli tiheyttä ja paksuutta. Ensi sijassa juuri tämä seikka erottaa maalauksen piirroksesta.

Piirtäminen kyseenalaistaa muodon ja aineen tavanomaisen erottelun, sillä piirroksessa ne kytkeytyvät poikkeuksetta yhteen. Piirtämisen raaka-aine eli viiva on muodotonta, sillä se ylittää kaikki olemassa olevat muodot. Juuri aine muovaa jokaisen muodon (Michaud 2010, 81). Piirtämisellä on Nancyn muotoa ja sen puutetta, muodottomuutta, koskevalle ajattelulle myös oleellista ja laajempaa merkitystä: piirtäminen tekee näkyväksi muodon alkamisen ainutkertaisuuden, sen muotoa antavan voiman ja liikkeen ja vedot, jotka jättävät 
aina jäljen. Juuri tästä syystä muotoa ei voi olla olemassa ennen piirtämisen tekoa eli yksinkertaisimmillaan käden liikettä. Piirros on muoto, jota ei vielä ole tai joka ei ole vielä muotoutunut - Nancy kuvaa piirrosta "lahjaksi, keksinnöksi, muodon synnyksi” (Nancy 2009, 11). Siksi jokainen taiteilijan teokseensa vetämä viiva on merkityksellinen ja se erottuu: kukin piirto ja piirre muuttavat ilmestyessään koko kuvan (mt., 120-130).

Halu määritellä taiteelle ominaiset muodot on monien taideteorioiden pyrkimys. Nancy suhtautuu taideteoksen muotoon toisin: hänen mukaansa muoto suuntautuu aina kohti jotakin, joka on sen ulkopuolella, ja muoto kuuluu ennalta tuntemattomaan ulottuvuuteen (outre-forme) (vrt. Michaud 2010, 81). Tätä muodon muodottomuutta juuri piirtäminen tuo erityisen hyvin esiin. Piirrosten muoto tai piirrosjälki "kesyttää" muodottoman eli antaa sille näkyvän hahmon, mutta asiat tulevat näkyviksi myös siten, että muoto koskettaa omaa rajaansa ja avautuu tällä tavoin kohti näkymätöntä. Muoto ei siis tarkoita Nancylle enää mitään ideaalista, eikä se ole asioiden takana oleva käsite tai idea, vaan muoto on toimintaa eli muodon ottamista. Varsinkin tässä Nancyn ajattelu lähestyy romantiikkaa ja käsitettä forma formans eli "muotoutuva muoto" (Nancy 2009, 30-33). Se merkitsee jotakin vasta muotoutumassa olevaa ja uusien asioiden keksimistä. Uuden luomisesta käsin puolestaan avautuvat kaikki muut muodot taiteessa, jota eivät rajoita käsitteet tai säännöt.

Romantiikan aikaan alkoi antiikista asti vallinnut ajatus taiteen materian ja muodon luonnollisesta sopusoinnusta rapautua, ja Nancyn tulkinta tuntuukin reagoivan juuri varhaisromantiikan teorioihin. Niissä filosofia ja taide yhdistyvät saumattomasti, ja idealismi edellyttää materiaalisuutta konkreettisine ilmiöineen - väreineen, sävyineen ja tiheyksineen. Nancyn kuvailema muodottomuus voidaan kuitenkin rinnastaa myös Kantin ylevän käsitteeseen ja etenkin Jean-François Lyotardin tulkintaan ylevästä. Lyotardin mukaan ylevässä on kyse juuri muotoa kaihtavasta materiasta eli taiteen muotoon palautumattomasta aineksesta, esimerkiksi kuvataiteessa väreistä ja musiikissa äänen sävyistä (esim. Lyotard 2001). ${ }^{4}$

Nancylle juuri muoto ja sen perustana oleva muodottomuus perustuvat ajatukseen esittämättömän esittämisestä, aiheesta, jonka paradigmaattinen esimerkki Lyotardin ajattelussa on ylevän kokemus. Jos piirtämisen teossa syntyy muotoja, ne voivat Nancyn mukaan olla esitys ainoastaan esityksen tapahtumasta, jossa muoto muotoutuu itsekseen (Nancy 2009, 49). Piirtämisessä syntyville muodoille ei siis ole olemassa transsendentaalista tai ideaalista mallia. Nancy kuitenkin tarkentaa, että taiteilijalla saattaa olla käytössään päämääränä malli tai kohde, mutta tällaisen olemassaolo ei kuitenkaan sanele piirtämisen tekoa (mt., 50). Näin muoto osoittautuu pohjimmiltaan muodottomuudeksi, tai muotoja on olemassa vain niiden syntymisen tilassa.

Taiteen tehtävä on Nancyn filosofiassa esittää, miten asiat tulevat läsnä oleviksi. Läsnäolon puhjetessa esiin kukin esitys on alun perin vailla merkitystä. (Nancy 1988b, 82.) Kuvataiteesta puhuttaessa tämä tarkoittaa, että taideteos on muodon tai mallin antamista sille, millä ei ennen toteutusta vielä ole mallia (Nancy 1990, 318-319). Näin teos, esimerkiksi piirros tai maalaus, antaa itse olemassaololle muodon ja aistittavan mielekkyyden. Tästä seuraa, että taiteeseen kuuluva muodonanto on pakenevaa ja yllätyksellistä, sillä taideteoksen valmista muotoa figuurin tai hegeliläisen Idean merkityksessä ei ole sellaisenaan tavoitettavissa, ei taiteen näkyvien eikä näkymättömienkään mallien joukossa. Nancylle taiteen muoto on siten läsnäoloa, jolla ei ole alkuperää, mutta toisaalta kyse ei myöskään ole muodon puhtaasta poissaolosta - taiteen tuleminen läsnäolevaksi perustuu muodon katoamiseen ja syntyy vain tästä katoamisesta ja teoksia tuottavan liikkeen keskeytymisestä. Muoto pakenee jatkuvasti taiteilijan otteesta. Siksi piirros esittää muotoutuvan muodon eli yliaistisen idean itsensä, mutta niin, että ky- 
seinen idea syntyy vasta piirroksen muodossa, piirretyssä jäljessä (mt., 19). Sen sijaan, että piirros jäljittelisi asioita, se näin osoittaa koko mimeettisyyden mallin syntymisen periaatteen ilman, että malli viittaisi jo olemassa olevien hahmojen saattamiseen näkyviksi piirtämisen keinoin (mt., 31).

Siten Nancyn teoria piirtämisestä perustuu ajatukseen, että jokainen piirrettäessä syntyvä jälki viittaa kaikkien olemassa olevien muotojen ulkopuolelle ja muodon syntymisen loputtomaan mahdollisuuteen. Piirroksen todellinen muoto on vielä muotoutumaton ja vasta tulossa; se on päämäärä itsessään ja piirtämisen teko, viivan veto, joka edeltää piirtäjän halua näyttää kyseinen muoto ja jättää siitä jälki (mt., 122). Jokainen viivan synnyttämä kuvio on hahmon antamista asioille, ja viivan saa aikaan juuri piirtämisen vaatima teko tai liike (mt., 19, 124).

\section{KATOAVA KUVA}

Nancyn ajattelussa piirros asettuu jännitteeseen, joka vallitsee viivan synnyn ja häviämisen väliin - hetkeen, jolloin kuva on muotoutumaisillaan, mutta ei voida vielä sanoa, että se olisi edessämme läsnä pysyvästi ja kokonaisena. Siksi mikä tahansa viivoista koostuva kuva vetäytyy katseeltamme ja pakenee: koska kuva on muodottoman muoto, se on luonteeltaan välitila, siirtymistä tilasta toiseen. Kuva on siten katoamista ja hajautumista. (Nancy 2007, 9-10.)

Kirjassaan $\grave{A}$ plus d'un titre Nancy käyttää kuvan muodon katoamisesta esimerkkinä italialaisen Valerio Adamin (s. 1935) lyijykynällä piirtämää muotokuvaa. Kuvassa nähdään Jacques Derrida yhdessä kissansa ja kirjojensa kanssa. Kuvan ja tekijän valinta on tuskin sattumaa, sillä Adamin teokset ovat kiinnostaneet Derridaa itseäänkin - Derrida kirjoitti Adamista jo teoksessaan La Vérité en peinture ("Totuus maalaustaiteessa", 1978).
Derridan kuvassa merkittävää on sen suhde malliinsa. Kuvan tekijä, Adami, on määritellyt piirroksen "allegoriseksi muotokuvaksi", ja se on valmistunut Derridan kuolinvuonna 2004 (Nancy 2007, 15). Piirroksen oikeaan alakulmaan taiteilija on merkinnyt kuvan valmistumisen päivämäärän "27.1.04". Päiväyksen kirjaaminen sisältää Nancyn mukaan kuitenkin paradoksin: valmistuttuaan mikä tahansa kuva siirtyy välittömästi ikuisuuteen. Päivämäärän esittäminen on siten ristiriitaista, sillä kuva, esitti se elävää tai kuollutta, on aina jo siirtynyt ajasta ikuisuuteen, ajan ulkopuolelle. Siellä se on läsnä kaikkina aikoina, ei vain päiväyksen ilmoittamana hetkenä, joka on ohitse yhtä nopeasti kuin on se on syntynyt. (Mt., erit. 33-37.)

Adamin piirroksen tarkastelussa tiivistyy monia Nancylle ja samalla myös Derridalle tärkeitä tapoja luonnehtia kuvia ja erityisesti piirtämistä - eikä tällöin voida aina erottaa, milloin puhe on Nancyn ja milloin Derridan ajattelusta. Derrida on Nancyn kirjan aihe, mutta myös Derridan varsinkin teoksessaan Mémoires d'aveugle ("Sokean muistelmat" tai "Muistumia sokeasta", 1991) esittämä käsitys piirustuksen ja viivan luonteeseen kuuluvasta vetäytymisestä ja katoamisesta on Nancylle merkityksellinen.

Nancyn mukaan mitä tahansa "olemista on vain katoamisen kautta". Kun oleminen on kadonnut, se on olemassa juuri poissa olevana. (Nancy 2007,10.) Derridaa esittävän piirroksen kadonnut hahmo ilmestyy tästä lähtien meille ikuisesti katoavana kuvana, joka puolestaan palaa eteemme lakkaamatta ja niin sitkeästi, että hahmosta jää merkiksi vain poissaolo, jonka kukin piirto palauttaa näkyviin. Nancyn luonnehtimalla kuvalla tuntuu olevan merkin rakenne, sellaisena kuin Derrida, Maurice Blanchot ja jo alun perin Hegel sitä kuvaavat, se on hauta. Merkki, niin sana kuin kuvakin, pyrkii esittämään kohteen poissaolon ja tekee näin poissaolon itsensä todelliseksi. Merkit osoittavat olemisen tyhjyyteen, siihen, mikä jää jäljelle niiden irtauduttua kohteestaan, sen olemisesta todellisuudessa (esim. Derrida 


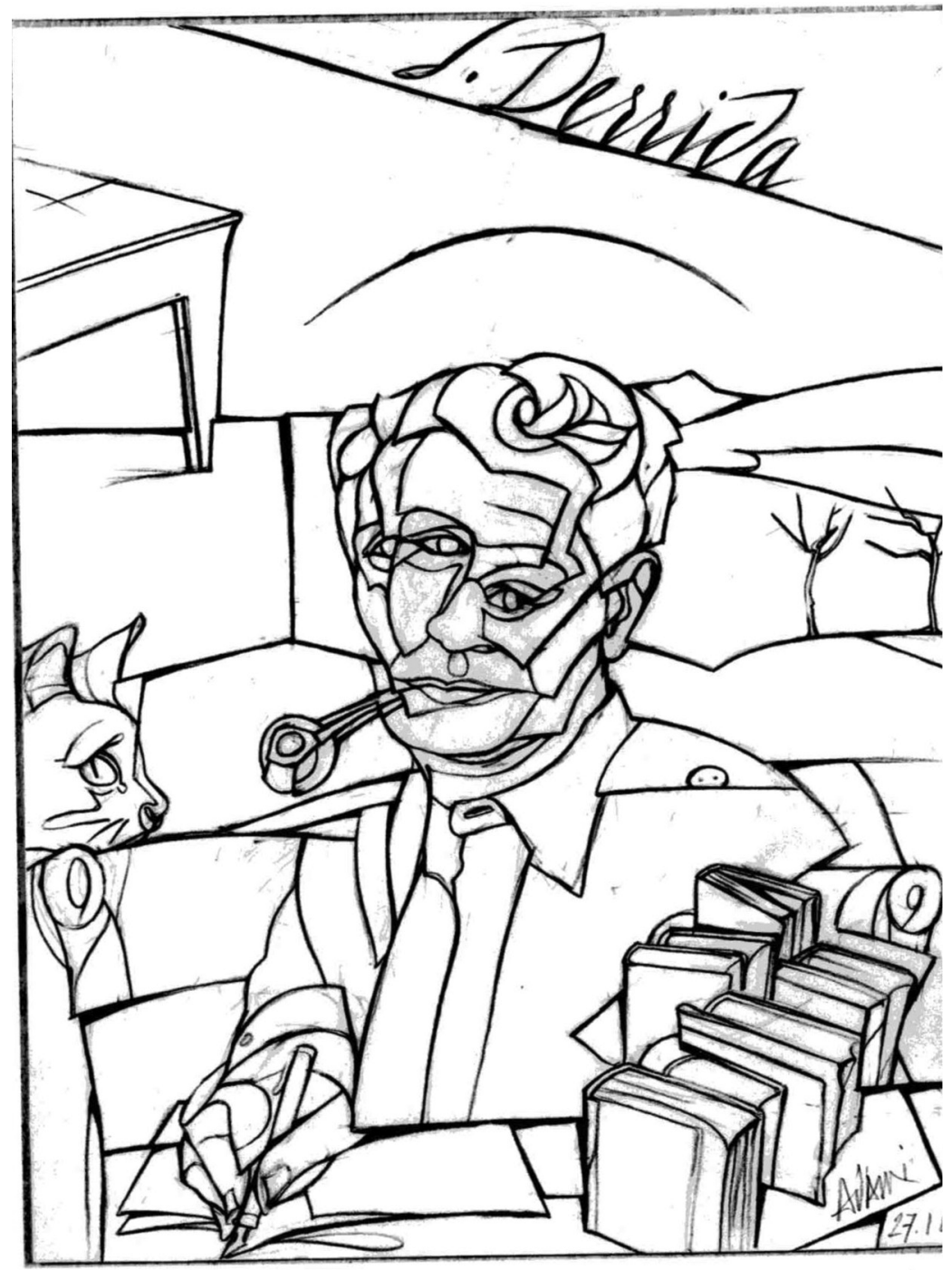

VALERIO ADAMI: JACQUES DERRIDA, ALLEGORINEN MUOTOKUVA (2004, LYIJYKYNÄ PAPERILLE). 
1972, 95; Blanchot 2001, 19-21; vrt. Blanchot 2003, 28-30).

Ainoastaan kuollut kuva on enää todellinen, ei kuvan esittämä henkilö. "Olla kuollut" tarkoittaa olemista, joka ei enää ole. Nancylle kuva ilmentää siksi loputonta odotusta, yhä uudelleen esitettävää pyyntöä olemassaolon ja mielekkyyden ihmeestä, joka voidaan havaita vain kuvan olemassaolon rakenteeseen kuuluvassa "tuhlauksessa" (Nancy 2007, 11). ${ }^{6}$ Adamin piirroksessa näemme Derridan, joka "on kadonnut, hävinnyt näkyvistä - kuvassa on hajonnut viiva, joka lähtee sulkakynän kärjestä, jatkuu aina piirroksen reunaan asti ja väistämättä häviää sen ulkopuolelle, koko muun paperin tyhjyyteen" (mt., 15). Muotokuvassa tulee esiin tapa, jolla malli, Derrida, on kuvassa: hänen olemisensa on läsnäolon ja olemuksen puuttumista, jatkuvaa liikettä kuvan pakenemisen ja esiin tulemisen välillä. Nancyn mukaan Derridan oleminen piirroksessa on "hänen perimmäistä, pohjatonta vetäytymistään pinnasta, johon piirros ei koverra uurteita ja jota se ei avaa mitään ulkopuolista maailmaa kohti" (mt., 16).

Muotokuva esittää idean todellisen muodon vailla muotoa, sen tulon, lähdön, katoamisen ja hajaantumisen kaukana mistä tahansa yleisestä, käsitteellisestä ideasta. Nancyn mukaan kysymys on tästä syystä "sinusta vailla mitään ideaa tai ideaalia, jälki sinun ohimenostasi", ja kuvassa on "Sinä ilman identiteettiä" (mt., 19). Kuva puhuttelee, ja sen hahmo tai ruumis on olemassaoloa paikallisuuden merkityksessä. Muotokuva voi siksi olla mikä tahansa, ehkä jopa kuka tahansa; merkityksellistä siinä on välimatka, ero tai kuilu, joka erottaa kuvauksen kohteen todellisen "itsen" näkyvästä kuvasta itsestään (Nancy 2007, 20-21). Nancyn määritelmän mukaan kuva on peräisin juuri muotokuvan äärettömästä ironiasta. Kuvassa näet asettuu välimatkan päähän se, mikä voi erota itsestään, jotta se voisi esittää itsensä vain samalla yllättymällä siitä, mitä merkitsee "itse", "joku" tai "sama", ja jota "häkellyttää" esitetyksi tulemisen tosiasia (mt., 28). Nancyn korostama etäisyys Derri- daa esittävän muotokuvan ja sen aiheen, nyt jo kuolleen henkilön, välillä muistuttaa etenkin Blanchot'n tunnetuksi tekemää ajatusta taideteoksesta, joka ilmenee tyhjyytenä ja hautana. Samalla poissaolo on kuitenkin välttämätöntä, jotta teos voisi viitata itsensä ulkopuolelle: vain siksi, että kohde on poissa, kuva tai kieli voi esittää asioita. (Blanchot 2001, 21.)

Kuvan olemassaoloon kuuluu siten erottamattomasti katkos esityksessä, joka on samalla esityksen itsensä katkonaisuutta ja epäjatkuvuutta. Teoksessaan Mémoires d'aveugle Derrida on kirjoittanut esityksen fragmentaarisuudesta tavalla, joka nähdäkseni on heijastunut Nancyn piirtämistä käsitteleviin teksteihin. Derridan analyysin tärkeimpiä käsitteitä ovat ranskan sanat trait ja retrait. Trait'n merkityksiä ovat "veto", "piirto" ja "viiva", retrait'n vastaavasti "vetäytyminen" ja "poissaolo". Toistoa ilmaisevan re-etuliitteen ansiosta vetäytymistä ilmaiseva retrait sisältää kuitenkin myös uuden vedon mahdollisuuden, mahdollisuuden uusien viivojen piirtämiseen. Mémoires d'aveugle -kirjassa Derridan viivan käsitteeseen rinnastuu ajatus, että jokainen viivan veto piirroksessa on kuin kirjoitusta siinä mielessä, että se on jälki jostakin, jota ei enää ole ja joka toisaalta on toistettavissa eli vedettävissä uudelleen (ks. Wolfreys 2004, 87). Kuva ja sen jokainen viiva on läsnä oikeastaan vain paperille jätettyjen jälkien perustalta ja katsojan muistin eli kuvatun poissaolon varassa. Samalla piirros on vasta tapahtumaisillaan ja sen muoto hahmottuu suhteessa viivojen paljouteen ja kokonaisuuteen tullakseen siksi mitä se on. Piirros on siis jatkuvasti vasta tulemaisillaan jonkinlaiseksi. (Derrida 1991, 50, 58.)

Derridalle piirustus on siis ikuisesti toinen: se eroaa kaikesta muusta - ja koska se on taideteos, se myös erottuu kaikesta muusta - ja eroaa myös itseensä nähden. Viivaa eli piirroksen merkkejä ei ole olemassa vain "yleisesti", eikä niillä ole läsnäoloa "yleensä", vaan tekstien tapaan piirros koostuu puhtaista jäljistä eli eroista (Derrida 1972, 12, 206). Piirretyistä viivoista muodostuva kuva Adamin teoksessa 
- Derridan hahmo - on viime kädessä vailla identiteettiä tai viittauksen kohdetta; kuvan mieli syntyy vain omassa mielessämme, sillä kuva itsessään ei muistuta mitään eikä ketään. Viiva ylittää mallin. Siten kaikki, mikä liittyy tunnistamiseen, toisin sanoen kaikki käsitykset piirroksen ja kuvatun hahmon yhdennäköisyydestä, ovat tulosta välimatkasta kohteen ja sen esityksen kesken. Tunnistamisen kokemus syntyy Nancyn mukaan ainoastaan siitä tosiseikasta, että kuva ensin muistuttaa itseään ja vain omaa muistuttavuuttaan, ei siis varsinaisesti kohdettaan. Vain tällä ehdolla muotokuva voi olla mielestämme jonkun tai jonkin näköinen. (Nancy 2007, 84; Nancy 2000, 51.)

\section{PIIRRETTY KUVA}

Kuvassa esityksen kohde nähdään siis sellaisenaan, pelkkänä kuvana. Sen takana ei ole mitään toista, yliaistimellista todellisuutta tai ideaalia, eikä kuvalla ole identiteettiä. Sen sijaan näemme vain jäljen jostakin ohikiitävästä asiasta. Tästä huolimatta, Nancy huomauttaa, jälki on kuitenkin aina jonkin värinen, sillä ei ole olemassa värittömiä viivoja. (Nancy 2007, 19; Nancy 2009, 10.) Väri on Nancylle asia, joka kertoo taideteoksen ja sen osatekijöiden ainutkertaisuudesta, mihinkään muihin teoksiin palautumattomasta singulaarisuudesta. Jokainen taideteos on väriltään - ja kaikilta ominaisuuksiltaan - jonkinlainen, eli sillä on paikallisväriä. Paikallisväri on intensiteettiä, olemassaolon jäljittelemätöntä tapahtumista, taajuutta ja sävyjä ajassa ja paikassa. Se ei niinkään ole asioille omaa tai niiden ominaisuus, vaan syntyy erilaisista suhteista. (Nancy 1996b, 31; Nancy 1997, 15.) Viivallakin on väriä esimerkiksi sen suhteessa pohjaan, josta viiva nousee esiin jonkinlaisena. Näin avautuva näky ei ole asiassa itsessään, vaan paikallisvärin läsnä oleminen on ennemminkin teko tai värin toimintaa (acte) juuri samaisessa ympäristössä kuin näkyvä asia" "itse", sillä tarkkaankin esittä- miseen perustuvassa värin käytössä päädytään lopulta aina korkeintaan likiarvoihin.

Kun Nancy puhuu piirtämisestä, kyseessä ei näin ole maailman jäljittely vaan piirros, joka tuottaa ideoita, ajatuksia, mieliä ja totuuksia heti ilmetessään. Näitä totuuksia ei sellaisinaan voida tunnistaa, koska me emme vielä tunne niitä: tällaiset totuudet vasta muodostuvat jonkinlaisiksi (Nancy 2009, 20-22). Nancyn "muotoutuva muoto" on siis vastakohta klassiselle käsitteelle belle forme - "hyvä" tai "kaunis muoto" (vrt. Kant 1952, § 48). Piirroksissa esiin tulevat, yhä muotoaan etsivät ideat ovat muotoja sille, millä ei ole sääntöjä tai ehtoja. Näiden ideoiden perustalta syntyvät kaikki muut muodot ja propositiot. (Michaud 2010, 81; vrt. Nancy 2009, 22.)

Viiva tuo esiin loppuun saatetussa muodossa piilevän epätäydellisyyden. Tällainen epätäydellisyys ei tarkoita kuitenkaan puutteellisuutta, vaan sitä, että on jotakin täydentymätöntä, joka piirtäjän mielessä ylittää kaikki täydellisyyden mittapuut (Nancy 2009, 128). Siten täydellisyyden vetäytyminen tai pakeneminen kuuluu jokaiseen viivanvetoon: viivan suunta on aina kohti ajattelemattoman aluetta, jota ei ole vielä olemassa. Viiva on siten määrittelemätön - sitä ei voida nimetä, ei vetää loppuun eikä viimeiseen asti. (Mt., 11.) Silti viivan epätäydellinenkin muoto on sellaisenaan täydellinen, eli se täydellistyy viivan aistimellisessa ilmentymässä, ei ideaalisella tasolla, ajattelussa tai filosofiassa. Nancyn ajatus viivasta on siis jotakin toista kuin mitä vaikkapa Hegel kirjoittaa taiteen tulemisesta täydelliseksi nimenomaan yliaistisen Idean tai Totuuden alueella eli jossakin muualla kuin materiaalisessa todellisuudessa.

Viivan viimeistelemättömyyden ja vetäytymisen ajatukset yhdistävät Nancya ja Derridaa. Heille on yhteistä ja heitä erottaa monista muista piirtämisen ajattelijoista käsitys, ettei piirustus ole koskaan läsnä kokonaisena ja "sellaisenaan". Piirroksen muoto syntyy lopulta perustattomuudesta, ei-minkään pohjalta: viivaa ei ole olemassa ennen ruumiin liikkeen 
antamaa eleen välitöntä mielekkyyttä. Viivassa saa hahmon piirtämisen teon ruumiillisuus, käden ja jäljen toinen toistaan liikuttava yhteistyö, jonka taideteoksen väline ja tekniikka puolestaan tekevät konkreettisesti näkyväksi. (Ks. Nancy 2009, 50, 122-123.) Viiva on aina vasta tulossa siksi mikä se on, ja se on olemassa vain piirtämisen hetkellä syntyvässä ratkeamattomassa jännitteessä. Derridan lailla Nancy kyseenalaistaa käsityksen siitä, että piirros ja sen tärkein tekijä, viiva, representoisivat maailmassa olevia muotoja tai antaisivat niille kiinteät ääriviivat. Ääriviivat eivät synny todellisuutta jäljittelemällä, vaan ne voidaan

\section{VIITTEET}

1. Kirjan nimi À plus d'un titre sisältää sanaleikin. Ranskankielinen sanonta à plus d'un titre tarkoittaa "monella tapaa", mutta kirjaimellisesti se voidaan myös ymmärtää merkityksessä "lukuisia nimiä". Samalla nimi viittaa ilmaisuun plus d'un, jolla Nancy eri teoksissaan kuvaa olemisen luonnetta: olemista on aina "yhtä enemmän", jotta olemisesta ylipäätään on mahdollista puhua. Siten Nancyn mukaan olemisen instansseja, olevia, on aina välttämättä useita, eikä voida ajatella vain yhtä, yleistä ja kaikenkattavaa "olemista". Toisaalta plus d'un voi merkitä ranskaksi "ei enää yhtäkään”. (Ks. Nancy 2007, 96.)

2. Le Plaisir au dessin -kirjan esimerkkitaiteilijoita ovat italialainen Valerio Adami ja ranskalaiset nykytaiteilijat Pierre Alechinsky, Jean Le Gac, Ernest PignonErnest, François Rouan, Gérard Titus-Carmel ja serbialainen Vladimir Veličković.

3. Italian kielen piirtämistä ilmaiseva sana disegno viittasi jo 1300-luvulla maalauksen, kuvanveiston ja arkkitehtuurin yhteiseen perustaan. Disegno (latinaksi graphis) merkitsi juuri kuvataiteeseen sisältyvää älyllistä tekijää, joka kohotti käsityötaidon taiteeksi.

4. Kauneuden kokemuksessa subjektin käsityskyvyn ja esittämisen kyvyn eli kuvittelukyvyn kesken on sopu- antaa vain taideteoksissa. Valmiiden viivojen sijaan Nancy pitää viivaa enemmänkin pisteenä, nollakohtana, josta käsin olemista voi ilmetä. Viiva itse on olemisen alku, sillä se jakaa ja luo tilaa: viivat antavat tilan esityksille kulloisenkin muodon ja oman ainutlaatuisen totuutensa. Siten viivan totuus ei ole maailmassa, vaan se kaikkineen on erottumista ja erottamis$t a$. Piirroksen olemassaoloa on siten ajateltava eroja tuottavista suhteista käsin. Nämä tuovat näkyviin syntymäisillään olevan idean, jonka toteutuminen valmiina teoksena ja täydellistyminen ovat aina vasta edessäpäin, aina yhtä vetoa vailla.

sointu, jolle ei ole sääntöä. Siten kauneuden tunteessa on kysymys muodon antamisesta aistimelliselle ainekselle. Ylevä taas on toisenlainen, ristiriitainen tunne. Se ilmenee, kun kuvittelukyky ei onnistu esittämään kohdetta, jonka käsityskyky antaa sille. Subjektin mielen kykyjen välille syntyy näin konflikti, kun kuvittelukyvyn tehtävänä on saattaa aistimusten antama "massa" eli materia käsiteapparaattiin ja antaa sille muoto. Tällä tavoin ylevän kokemus edellyttää, että meillä on idea maailmasta, mutta emme kykene kuvaamaan sitä aistittavalla kohteella. Ylevässä kyse on Lyotardille siis ilmaisemattomasta ja siitä tosiasiasta, että jotakin tapahtuu: tilanteesta, jossa tapahtuminen itse ei saa muotoa. Se, mikä tapahtuu, on taideteosten materiaalinen tosiasiallisuus. (Lyotard 2001; ks. myös Lyotard 1989.)

5. "Ideasta" Nancy käyttää ranskan sanaa dessein, joka on kirjoitusasultaan lähellä "piirrosta", dessin - äännettäessä sanojen välinen ero ei edes kuulu (ks. Nancy 2009, 82).

6. "Tuhlauksella" Nancy viitannee Georges Bataillen tarkoittamaan asioiden materiaalisen olemassaolon perusolemukseen, muodottomuuteen, joka ei palaudu käsitteisiin (vrt. Bataille 1967, 63-64). 
Barasch, Moshe (1998) Theories of Art, 3: From Impressionism to Kandinsky. Routledge: New York.

Barthes, Roland (1989/1977) "Cy Twombly eli non multa sed multum”. Suom. Leevi Lehto. Teoksessa Jaakko Lintinen (toim.) Modernin ulottuvuuksia. Helsinki: Taide, 148-166.

Bataille, Georges (1967) La part maudite. Paris: Minuit.

Blanchot, Maurice (2001/1949) "Kirjallisuus ja oikeus kuolemaan”. Suom. Outi Alanko. Nuori Voima 2001:6, 14-28.

Blanchot, Maurice (2003/1955) Kirjallinen avaruus. Suom. Susanna Lindberg. Helsinki: Ai-ai.

Derrida, Jacques (1967) De la grammatologie. Paris: Minuit.

Derrida, Jacques (1972) Marges de la philosophie. Paris: Minuit.

Derrida, Jacques (1991) Mémoires d'aveugle: l'autoportrait et autres ruines. Paris: Réunion des musées nationaux.

Heidegger, Martin (1995/1935-36) Taideteoksen alkuperä. Suom. Hannu Sivenius. Helsinki: Taide.

Kandinsky, Wassily (1981/1911) Taiteen henkisestä sisällöstä. Suom. Marjut Kumela. Helsinki: Suomen Taiteilijaseura.

Kant, Immanuel (1952) The Critique of Judgement. Käänt. James Creed Meredith. Oxford: Clarendon Press [Kritik der Urteilskraft, 1790].

Klee, Paul(1987/1924) Modernista taiteesta. Suom. Kimmo Pasanen. Helsinki: Suomen Taiteilijaseura.

Lyotard, Jean-François (2001/1988) "Estetiikan tila ylevän jälkeen”. Suom. Markku Lehtinen. Nuori Voima 2001:4-5, 24-27.

Lyotard,Jean-François (1989/1983) "Ylevä ja avantgarde”. Suom. Hannu Sivenius. Teoksessa Jussi Kotkavirta ja Esa Sironen (toim.) Moderni/postmoderni. Helsinki: Tutkijaliitto, 159-178.

Merleau-Ponty, Maurice (2012) Maurice Merleau-Ponty: filosofisia kirjoituksia. Suom. ja toim. Miika Luoto ja Tarja Roinila. Helsinki: Nemo ["Silmä ja henki", 1960].

Michaud, Ginette (2010) "Outlining Art: On Jean-Luc Nancy's Trop and Le Plaisir au dessin". Journal of Visual
Culture 9:1 (April 2010), 77-90.

Nancy, Jean-Luc (1988a) L'Expérience de la liberté. Paris: Galilée.

Nancy, Jean-Luc (1988b) L'Oubli de la philosophie. Paris: Galilée.

Nancy, Jean-Luc (1990) Une pensée finie. Paris: Galilée.

Nancy, Jean-Luc (1992) "Un sujet?” Teoksessa Dominique Weil (toim.) Homme et sujet. Paris: Harmattan, 47-114.

Nancy, Jean-Luc (1993) Le sens du monde. Paris: Galilée.

Nancy, Jean-Luc (1994) Les Muses. Paris: Galilée.

Nancy, Jean-Luc (1996a) Etre singulier pluriel. Paris: Galilée.

Nancy, Jean-Luc (1996b/1992) Corpus. Suom. Susanna Lindberg. Helsinki: Gaudeamus.

Nancy, Jean-Luc (1997) Technique du présent: essai sur On Kawara. Villeurbanne: Nouveau Musée / Institut d'art contemporain.

Nancy,Jean-Luc (1998) Heideggerin "Alkuperäinen etiikka". Suom. Kaisa Sivenius. Helsinki: Loki.

Nancy, Jean-Luc (2000) Le Regard du portrait. Paris: Galilée.

Nancy, Jean-Luc (2003) Au fond des images. Paris: Galilée.

Nancy, Jean-Luc (2007) À plus d'un titre: Jacques Derrida. Paris: Galilée.

Nancy, Jean-Luc (2009) Le Plaisir au dessin. Paris: Galilée.

Nancy, Jean-Luc (2010) ”Art Today”. Käänt. Charlotte Mandell. Journal of Visual Culture 9:1 (April 2010), 91-99.

Platon (2007) Valtio. Suom. Marja Itkonen-Kaila. Helsinki: Otava.

Saarinen, Veli-Matti (2011) Taiteen Elämä ja Kuolema. Helsinki: Kuvataideakatemia.

Schlegel, Friedrich (1971) Friedrich Schlegel's Lucinde and the Fragments. Käänt. Peter Firchow. Minneapolis: University of Minnesota Press.

Wolfreys, Julian (2004) "Art”. Teoksessa Jack Reynolds ja Jonathan Roffe (toim.) Understanding Derrida. New York: Continuum, 84-92. 